Kalikst Nagel

\title{
Human rights and the law of human rights: a positive legal regulation of an ontic reality
}

\section{Introduction}

Everybody talks about human rights: during informal meetings, in popular newspapers, as well as during academic conferences or in academic dissertations. "Human rights" are guaranteed by numerous acts of positive law - constitutions, covenants, acts of parliament, international declarations. Every attempt to guarantee these rights is always based upon a certain way of understanding what they are. What can be seen after analysing acts (being currently in force) of positive law protecting these rights is that all "human rights" share one attribute: vagueness and lack of definitiveness as to their content. This causes a serious danger, because achieving definitiveness as to the content of human rights is necessary in order to accomplish the purpose of all law: effectiveness. Lack of this definitiveness may lead to violations.

The fact that the role and importance of human rights is recognized must be treated as an undoubtedly positive phenomenon. Our whole civilisation should be built upon the fundament of recognition and legal protection of human rights, especially bearing in mind the horrors of World War II, when whole nations, including our own, were exterminated only because of nationality, which was understood in ethnic terms. We cannot allow this tragedy to ever fade away from the universal awareness of mankind because it protects us from the repetition of these tragic happenings. Nevertheless, it must be clearly stated that protection of human rights based solely on this awareness does not appear to be sufficient.

It seems quite obvious that no human activity, including all acts of positive law, will ever lead to such a state of affairs in which human rights will not be violated. Despite that, we should do whatever can be done to achieve such a state. What must be done in the first place is to construe, on the grounds of legal theory and the philosophy of law, a theory of human rights which could be used to interpret acts of positive law which are currently in force (including acts of international law) as well as to prepare drafts of new acts of positive law (na- 
tional and international), if they were thought to be necessary. It is an absolutely fundamental issue to find a definitive answer to the question "what really are human rights?"

\section{Historical perspective}

\section{The rationalist school of the natural law of human rights}

In order to find a proper answer to the question asked above, a short examination of what has been achieved in previous ages is necessary. H. Waśkiewicz states that the first concept of human rights was worked out in the 17th and 18th centuries by legal philosophers - representatives of the so called (rationalist) school of natural law ${ }^{1}$. According to this school, human rights are "subjective rights of public law, owed to every human being" , granted by the norms of natural law and because of that they were believed to exist somehow "above" positive law, which is merely an ordinance enacted in order to exercise natural law ${ }^{3}$. This makes human rights universal, inalienable and inviolable.

Understanding human rights in this way was an act of resistance against the absolutist tendencies to entrench the power of states. From this perspective, the demand for protection of human rights was somehow directed against the state.

To say that something is universal within a certain set is to state that it refers to all possible elements of a set which is being examined. The universality of human rights has three aspects, which are a personal aspect: they are owed (due) to every human being; a territorial aspect: they are owed (due) to every human being notwithstanding his/her location in the space or norms of positive law being there in force; a content aspect: it is invariable, notwithstanding the circumstances of the time and place.

Inalienability is the impossibility of renunciation of these rights in any way, including by performance of any act of law.

Inviolability means that no one can have the competence to deprive anybody of his/ her (human) rights, but also that everybody is forbidden from violating human rights owed to anybody. Nevertheless, violation of somebody's human rights does not cause its annihilation. This right is still owed (due) to this human being, despite the violation.

\section{The concept of relative human rights}

The way of understanding what human rights are as described above does not correspond with the way in which the governments of the $18^{\text {th }}$ century exercised their powers.

1 H. Waśkiewicz, Prawa cztowieka w flozofi prawa, [in:] Filozofia prawa a tworzenie i stosowanie prawa, Materiaty Ogólnopolskiej Konferencji Naukowej zorganizowanej w dniach 11 i 12 czerwca 1991 roku w Katowicach, ed. B. Czech, Katowice 1992, p. 205.

2 Ibidem.

3 Ibidem. 
States in the 18th and 19th centuries generally tended to extend their power into wider and wider areas of human activity.

Because of the contrast between the growing belief that human rights originate from natural law and are owed (due) to everyone on the one hand, and the reality of the exercising of power by governments at the end of 18th century on the other hand, states and societies achieved some kind of compromise. States granted positive-law human rights to their citizens. The content of these rights were for the most part similar to the human rights recognized by the school of natural law, but there was a fundamental difference: the basis, the source of these rights. According to what the school of natural law claimed, they were granted by natural law and governments could not change them and going even further: they were obliged to respect them. Contrary to this, the concept of relative human rights stated clearly that human rights are granted by positive law and states are allowed to deprive their citizens of them; granting human rights is an act of good will by a government, nothing more. From this standpoint, human rights are relative, because they are relativized to the act of enacting the norms of positive law ${ }^{4}$.

This way of understanding what human rights are was not the effect of systematic reflection by philosophers or lawyers. It was merely a result of the praxis of exercising power by European governments. This can be seen, for instance, in the texts of constitutions imposed by several monarchs in the late 18th century and in the 19th century. A few case studies concerning human rights were published at that time, but they analysed contemporary legislation and the philosophical substance of the problem was not taken into consideration. Very few legal theorists' works on this subject that were published at that time were written from the positivist standpoint and did not clarify the essence of human rights: how do they bind legislators? ${ }^{5}$

\section{The way of understanding human rights after World War II}

The trauma of World War II and totalitarianism (communism, Nazism), which affected much of the population all over the world, helped philosophers, politicians, academics as well as regular people - the world's public opinion, to realise that people, nations and states must recognise the absolute character of human rights and guarantee their protection. This nearly universal awareness resulted in the enactment of several fundamental legal documents (The Universal Declaration of Human Rights ${ }^{6}$, The International Covenant on Civil and Political Rights ${ }^{\top}$ ). The very fact that the system of protection of human rights is international suggests that these rights are, at least, culturally and politically intersubjective. What is more, the texts of these acts indicate unambiguously

4 Ibidem.

5 Ibidem.

6 Further referred to as: the Declaration.

7 Further referred to as: the Covenant. 
that human rights are objective and absolute. The most obvious reason for such a standpoint is the fact that these documents declare that the equal and inalienable rights of all members of the human family derive from the inherent dignity of the human person ${ }^{8}$. In this perspective, the concept of relative human rights can no longer be claimed to be adequate. It is an anachronism ${ }^{9}$.

This universal belief that human rights are absolute and objective cannot be omitted from the legal and philosophical discourse. Of course, the shape of current positive-law regulations cannot be a deciding argument in the discourse concerning what human rights are. This is so because positive-law regulations merely reflect what human rights ontologically are, what their ontic nature is, they only reflect what people think about human rights, but they do not necessarily show it adequately and correctly. An analysis of acts of positive law protecting human rights shows that the belief as to the ontological character of human rights, expressed in e.g. the Declaration and the Covenant, is universally shared. This belief is very important, because such a character of human rights cannot be proved in a way we used to call scientific. The universality of the belief as to the character, derivation and content of human rights can be an indicator of the accuracy of certain results of the ontic cognition of human rights. But it must be kept in mind that even a unanimous international consensus as to the nature and content of human rights cannot be treated as a basis, or a source of human rights.

It is worth realizing that the current international system of protection of human rights was not construed as an emanation of any universally accepted philosophical concept. The Universal Declaration of Human Rights and the International Covenant on Civil and Political Rights as well as the provisions of, e.g., the German constitution were enacted as a reaction to the scale of violations of human rights during World War II, often committed in accordance with the provisions of positive law. Political and legislative actions somehow anticipated philosophical and jurisprudential reflection. They were supposed to protect mankind from the repetition of those horrible events. This attempt to protect human rights has commenced a new trend: human rights are - to some extent - recognized in the practice of political and social life and, at least partly, not perceived in philosophical and legal discourse ${ }^{10}$.

What is particularly interesting, despite the fact that according to the Declaration and the Covenant, human rights are based on natural law (this is reflected by the reference to "inherent dignity"), the role of a state is precisely the opposite to what it was thought to be according to the concept of the (rationalist) school of natural law. In the 18th century the whole idea of human rights was somehow aimed against states and governments as

8 As it is stated in the Preamble of the Covenant.

9 H. Waśkiewicz, op. cit.., p. 207.

10 M. Piechowiak, Pojecie praw cztowieka, [in:] Podstawowe prawa jednostki i ich sqdowa ochrona, ed. L. Wiśniewski, Warszawa 1997, pp. 10-11 and literature indicated there. 
a limit to their power. Now states and governments are thought to be the main guarantors of these rights.

\section{The current paradigm of human rights}

\section{Introductory presuppositions}

When reading thoroughly through the acts of international law on human rights enacted after World War II, especially the Declaration and the Covenant, it can be clearly seen that human rights are understood in a certain way which constitutes some kind of paradigm. M. Piechowiak made an attempt to describe $i^{11}$.

It seems that within the current legal and philosophical discourse, it can be deemed incontrovertible that human rights are "rights owed to a human being solely because of the fact that he/she is a human being, notwithstanding any acts of positive law"12. What the precise meaning of the term "right" is will be clarified below.

M. Piechowiak noticed that "it should be recognized that a fundamental fact, which is perceived by the concept of human rights, is the relationship of each human being to good owed (due) to him/her. The existence of this relationship does not depend on anybody's actions, including enacting a positive law, and the fundamental objective of the protection of human rights is an all-embracing protection of this relationship"13. This statement reveals the very heart of what human rights are. To give an example: the life of a certain human being, as a good owed (due) to him/her, stays with him/her, as a being, in the relationship of adequacy and in the relationship of being owed. This relationship exists because of the inherent dignity of a person, based upon the ontological structure of this being. It is this adequacy, the state of being owed, which is ontological, which is inalienable, inviolable, universal and equal for everyone. It is this adequacy which has normative consequences: forbiddance of the violation of human rights and, for certain groups of entities, a command to take special care of certain human beings.

\section{Attributes of human rights}

Within the abovementioned paradigm, the four following attributes can be ascribed to human rights: inherence (being inherent), universality, inalienability, equality.

11 M. Piechowiak, Pojęcie praw... ; M. Piechowiak, Filozofia praw cztowieka, Lublin 1999.

$12 \mathrm{~J}$. Hersch, Human rights in western thoughts, [in:], Philosophical foundations of human rights, ed. A. Diemeriinni, Paris 1986, p. 132.

13 M. Piechowiak, Pojęcie praw..., p. 12. 


\section{Inherence}

Inherence appears to be the most fundamental attribute of human rights which construes the whole paradigm. It means the immanence, intrinsic quality or, even better, the ontic nature of human rights. It means that human rights derive from the very nature of a human being and are owed to him/her solely on the basis of the fact that he/she is a human being. This attribute is inherited from the (inherent) dignity of a person from which human rights are derived. A human being, solely because of who he/she is, possesses the dignity of a person which makes him a subject of human rights.

The first sentence of the Declaration's preamble states: "whereas recognition of the inherent dignity and of the equal and inalienable rights of all members of the human family is the foundation of freedom, justice and peace in the world". These words must be read together with the second sentence of the Covenant's preamble, which reads as follow: "Recognizing that these rights ("equal and inalienable rights of all members of the human family") derive from the inherent dignity of the human person". On this basis it can be firmly stated that human rights derive from the dignity of a human person and are owed to a human being solely because of this dignity. And because of that, human rights share all the attributes of human dignity.

The entitlement of every human being to all human rights does not depend on any human activity, including any legislative action. These rights are what people are owed. They are universal, absolute and objective. Nevertheless, people and states are under a positive duty not to violate these rights and, what is more, to protect them. Several documents of international law (e.g. the Declaration ${ }^{14}$ ) require states to enact norms of positive law guaranteeing them. These norms constitute the law of human rights. The difference between human rights and the law of human rights can clearly be seen. We must be aware of this fundamental distinction between human rights and the law of human rights, yet what is more important is that this distinction must be applied in the practice of political and legal activity.

In this context it is perfectly clear that neither a social contract, nor (however understood) the will of any nation nor even the unanimously articulated will of the whole human family can be claimed to constitute a normative basis of human rights. A social contract, the will of a nation or even the whole human family can be merely a reason for stating that norms construing a positive law system for the protection of human rights are binding. They do not grant human rights which are ontic and objective.

14 The third sentence of the preamble of the Declaration: "Whereas it is essential, if man is not to be compelled to have recourse, as a last resort, to rebellion against tyranny and oppression, that human rights should be protected by the rule of law". 


\section{Universality}

The universality of human rights derives from their inherence. If human rights are owed to a human being solely because he/she is a human being, then they are owed to every human being. If so, they are universal.

The universality of human rights is indicated in many provisions of, for instance, the UN Charter, the Declaration or the Covenant. Even the title of the Declaration indicates it, for it is after all, the Universal Declaration.

The content of this document also does not raise any doubts as to the universal character of human rights. The first sentence of the Declaration's preamble invokes the "equal and inalienable rights of all members of the human family"15. Then, in article 2 of the Declaration, it is stated: "Everyone is entitled to all the rights and freedoms set forth in this Declaration, without distinction of any kind, such as race, colour, sex, language, religion, political or other opinion, national or social origin, property, birth or other status.". It is the fact that every human being is entitled to all human rights ${ }^{16}$, which constitutes the very essence of the universality of human rights.

\section{Inalienability}

The inalienability of human rights, just like universality, derives from their inherence. If human rights are owed to everyone solely because of the fact that he/she is a human being, then until the end of his/her life a human being is a subject of these rights, notwithstanding any of his/her or anybody's else behaviour. Inalienability indicates, therefore, the impossibility of the (1) transfer (2) renunciation or (3) deprival of human rights. No act of positive law can deprive any human being or any group of human beings of their (ontic) human rights. The only effect of enacting a law which does not recognize and protect any ontic human right or deprive an individual or group of such a right is the fact that in this particular (positive) legal system this human right is not recognized and protected. Ontologically, this right is still owed to this individual/group and he/she/they is/are still entitled to it.

\section{Inviolability}

The fourth feature of human rights is their inviolability. This is not directly indicated in documents of international law on human rights, nevertheless, in several constitutions, including the Polish ${ }^{17}$ and German ones ${ }^{18}$, human dignity is declared to be inviolable.

15 "Whereas recognition of the inherent dignity and of the equal and inalienable rights of all members of the human family is the foundation of freedom, justice and peace in the world".

16 Not exactly to all the human rights because some goods are owed to people only in specific circumstances. Certain goods connected with, for instance, participation in political life are not owed to infants. Nevertheless, there are some goods (e.g. life), which are owed to everyone.

17 Art. 30: Inherent and inalienable human dignity is a source of liberties and rights of a man and a citizen. It shall be inviolable. Its respect and protection shall be a duty of public authorities.

18 Art. 1: „Human dignity is inviolable”. 
The inviolability of human rights shall be understood as such an attribute which causes that they "draw the line (of violation), which cannot be crossed even if the violation would bring a significant profit to mankind or even if it were done in compliance with the will of the majority of a particular society or even the whole of mankind" 19 .

\section{Interdependence and interrelation of human rights}

Every human right is linked with the others. All these rights and links between them constitute the system of human rights. While looking at this system it can be seen that, as was stated in the Vienna Declaration ${ }^{20}$, "all human rights are universal, indivisible and interdependent and interrelated".

This interdependence and interrelation of human rights derives from their mutual normative basis, that is human dignity and the integrity of human life in all its aspects. Human rights are entitlements to certain goods connected with all aspects of human life, which is integral. Because human rights are to protect human life as a whole, in its integrity, human rights are also integral, which means that all human rights compose a system and every right is its constituent part. Therefore, it must be recognized that "for the comprehensive development of the human person it is necessary to take into consideration all the aspects of the being which it constitutes: physical, psychological, moral and spiritual, both in the individual and social context" ${ }^{21}$. This demands the creation of "suitable social, political, economic, cultural, ecological etc. circumstances"22. This means that human rights are interdependent and interrelated.

Integrity, interdependence and the interrelation of human rights must be taken into consideration while formulating a catalogue of human rights. This catalogue should be construed adequately, that is, it should include all the rights with the proper balance between particular aspects of human life, represented by particular families of rights and particular rights.

\section{Equality of human rights}

\section{Introductory observations}

According to M. Piechowiak, documents of international law on human rights (especially the Covenant) indicate three aspects of the equality of human rights. The parties to it declared equality before the law, equal protection of the law and equality in the law.

19 M. Piechowiak, Pojęcie praw..., p. 17.

20 Vienna Declaration and Programme of Action Adopted by the World Conference on Human Rights in Vienna on 25 June 1993.

21 M. Piechowiak, Filozofia praw..., p. 123.

22 M. Piechowiak, Pojęcie praw..., p. 18. 
What is very important is that according to the Declaration, the demand for equality refers to human rights, whereas according to the Covenant it refers to the whole legal sphere, that is to all the social relationships regulated by positive law ${ }^{23}$. It is probably trivial, but seems to be worth mentioning: "the equality in this case does not equal the uniform treatment of everyone or allotting everyone the same. Equality is violated solely by treating, on an arbitrary basis, in a different way that which is not essentially different or, in the same way, that which is essentially different" ${ }^{24}$. The meaning of the terms "arbitrariness" and, above all, "essential difference" is relativized to some external value, that is, to human dignity. The three abovementioned aspects of equality shall be discussed below.

\section{Equality before the law}

The principle of equality before the law provides that every legal norm, every time it shall be applied, shall be applied equally. The fact that this principle was violated can be stated based solely on the content of a positive-law norm, which ascertains an addressee of the norm, the scope of application and the scope of regulation. If such a norm was not applied (by the public authorities) equally in every case (in at least one case it was not applied compliant to the content of this norm) then the principle of equality before the law was violated. What must be observed is that norms of positive law constitute a criterion for this examination of whether this principle is applied ${ }^{25}$.

\section{Equal protection of the law}

The principle of equal protection of the law refers to the content of the norms of a (positive) legal system. The question of whether this principle is violated is, in fact, the question of whether a particular legal norm equally protects "equal" goods or whether the same good is equally protected in "equal" circumstances. So, just as in the case of the principle of equality before the law, positive law constitutes a criterion for examination of whether a particular legal norm complies with this principle ${ }^{26}$. The demand for the equal protection of law is, in fact, the demand for the axiological and praxeological coherence of a particular legal system. It would be, of course, naive to think that this demand is absolute. Reality is so complicated that in certain circumstances certain goods cannot be protected at the same time in the same manner, because they conflict and at least one of them must be sacrificed.

23 M. Piechowiak, Filozofia praw..., p. 129.

24 Ibidem, s. 130, an author refers to: B. Pieroth, B Schlink, Grundrechte. Staatsrecht II, Heidelberg 1994, p. 118.

25 M. Piechowiak, Filozofia praw..., p. 130-131.

26 Ibidem, p. 131. 


\section{Equality in the law}

The principle of equality in the law refers to acts of enacting law. This principle is in fact a command, addressed to a lawgiver, to enact such a law which equally protects the fundamental rights of all individuals. In other words, it results in the forbiddance of enacting a law which, "on accounts of anything, would deprive anybody of his/her fundamental rights or would protect them poorly in comparison to the way in which the same rights of other individuals are protected"27.

It is important to observe that human dignity and human rights that derive from this dignity are the criterion for deciding whether there exists "an essential difference" and whether there is "an arbitrary differentiation" between "equal" subjects. This criterion is external to the legal system.

M. Piechowiak, after A. Michalska, states that the parties to the Covenant in article 26 expressed their belief that the principles of equality before the law and equal protection of the law are subordinated to the equality in the law principle (the non-discrimination principle $)^{28}$. Equality in the law is the reason for and the basis of equality before the law and the equal protection of the law.

\section{The non-discrimination clause}

Several provisions of many acts protecting human rights provide a catalogue of human attributes that cannot be treated as constituting an essential difference between people. It is worth realizing that it is an open catalogue. What is more, the phrase "or other status" indicates that no other "status" or attribute can be treated as constituting an essential difference and, in consequence, justifying discrimination. Every human being is entitled to all human rights solely because he/she is a human being, because of existing as a being of a human nature (essence).

\section{The welfare (global good) of a human being as a criterion for discrimination}

What must be kept in mind is the fact that the non-discrimination clauses are not strictly formal, because treating people who do and who do not have particular attributes in a different way does not necessarily mean that one of these groups is discriminated against. To state that a human being in a certain situation is discriminated against, it is necessary to take into consideration his/her welfare (the global good of a being). M. Piechowiak correctly - as the author of this article believes- states: "the fundamental determinant of discrimination is not solely the fact of differentiating (...) but the fact that this kind of behaviour endangers the human rights of a certain man or group of people"29.

27 M. Piechowiak, Pojęcie praw..., p. 24.

28 Ibidem, s. 132, an author refers to A. Michalska, Komitet Praw Cztowieka, Warszawa 1994, p. 110.

29 M. Piechowiak, Pojęcie praw..., p. 23. 
Of course, the absolute equality of everyone in every aspect is impossible to achieve and even not desired. Equality refers only to "taking into account, on equal footing, that everyone is intrinsically directed towards his/her personal development and his/her relation to means of realization of this development" 30 . M. Piechowiak provides an illustration of these assertions ${ }^{31}$ and states that certain human rights are only owed to certain groups of people, e.g. the parents of a child are entitled to certain rights connected with raising this child and no one else is entitled to these rights. Similarly, a citizen of a country is entitled to certain rights that are not owed to anyone who is not a citizen of this country.

\section{Human rights, norms and a legal system}

\section{Human rights as relationships}

M. Piechowiak perceives human rights as "relationships of a normative character"32, relationships between (at least) two elements: an entitled subject of a human right, that is a human being, to whom those rights are owed and certain good that is due to him/her (a set of positive for him/her circumstances). Using language worked out in the Poznan school of legal theory, those elements may be called: an entitled (or competent) subject, an object of entitlement or a competence.

Treating rights as relationships is not a new concept. It originates from antiquity, when the long tradition of thinking about people's rights (called in Latin "ius") as a relationship commenced.

The core of Piechowiak's understanding of what human rights are is an objectively existing two-element relationship: allocation of a man to a certain state of affairs that is owed to him/her. That is an essence of a human right, actually, that is a human right. According to Piechowiak, we may reasonably talk about human rights without determining an obliged subject and a means of protection or punishment for a breach of the right. This seems to be right.

A good example of what was stated above is an objectively existing relationship between a certain human being and his life, understood as a certain state of affairs that is owed (due) to him/her. This relationship may be called a relationship of adequacy and it is based upon the dignity of a human being, which it is derived from . The life is adequate to this human being and he/she is entitled to it. This relationship was proclaimed many times in documents of international protection of human rights, especially the Declaration and the Covenant. This proclamation was put into effect by stating that

30 M. Piechowiak, Pojęcie praw..., p. 23.

31 Ibidem.

32 M. Piechowiak, Filozofia praw..., p. 138. 
a certain state of affairs is an object of a human right - e.g. "Every human being has the inherent right to life." 33 In one of its meanings this sentence is an indicative sentence, based strictly on ontological grounds, so it cannot be as easily stated that it is true as in a reference to e.g. a sentence "Water boils at $100^{\circ} \mathrm{C}$ ". Nevertheless, the means of recognition that a sentence is true or false does not change the nature of the sentence - it still refers to reality and may be true or false. Such a sentence is not merely an opinion, the correctness of which cannot be verified. It describes reality.

In this sense we may say that human rights exist without using a metaphor, without putting the word "exist" into inverted commas, because this relationship actually exists (in the relational way of existing).

It is interesting to consider what it means when we say that a certain human being is entitled to a certain state of affairs. M. Piechowiak states that a state of affairs is "a due state of affairs (a subject of a right) when there is a relationship of adequacy between a human being and this state of affairs; such a relationship exists when the considered state of affairs realizes a globally understood good, the welfare of this human being”. So, a certain state of affairs is adequate for a human being when it is good for him/her, it realizes his/her welfare. The good of a human being is, according to Piechowiak, his/her personal development. That state of affairs is distinguished from other possible states of affairs because of the good, the welfare of a certain human being, relative to him/her. It is this human being, his/her existence and his/her dignity which is the basis of this distinction. What is more, in this context the good and welfare of a certain human being, his/ her personal development, shall be treated as "a reason for and, at the same time, an aim of human rights and their protection" ${ }^{34}$.

Thus, we may distinguish (1) a state of affairs that may be recognized as globally realizing a good, the welfare of a certain human being and (2) states of affairs that realize certain aspects of human existence and that, in this certain aspect, reflect this global good and the welfare of a certain human being. According to M. Piechowiak, these states of affairs realising particular aspects of a good and the welfare of a certain human being are subjects of particular human rights.

What must be observed is that a state of affairs globally realizing a good, the welfare of a certain human being is hard to recognize for human intelligence and probably will never be recognized as a whole, but we may recognize particular aspects of this global good, welfare, that is: we may recognize, as we used to call them, human rights.

\section{Is it possible to describe "the reality of human rights" with the use of norms?}

The protection of human rights is a derivative of their existence. Recognizing that a certain state of affairs is due to a certain human being we also recognize certain normative

33 International Covenant on Civil and Political Rights, art. 6.

34 M. Piechowiak, Filozofia praw..., p. 142. 
consequences of this fact. If the life of a certain human being is recognized to be due to him/her because of his/her dignity, then, because of this dignity, other people shall not violate his/her life. Therefore, because of the fact that certain states of affairs are due to a certain human being, other people are obliged to respect this fact. These consequenceobligations can be described by the use of norms. Thus, the existence of a human being and his dignity ontologically justify that several norms guaranteeing and protecting these states of affairs are in force.

On examining these normative consequences, we may think of the following groups of subjects: subjects obliged to recognize and respect human rights (all the human beings and their organisational forms) or subjects obliged to take special actions to protect these rights. A subject that belongs to the second group may be called, after saint Thomas Aquinas, "an official who has custody of a whole multitude" or "who has custody of a community"; in our social and political context: a state).

Norms describing the normative consequences of human rights are justified ontologically. Using the existing language of jurisprudential discourse they should be treated as moral norms. They may and, in fact, should be in force on the basis of thetical justification too - after, of course, enacting a proper legal act. It seems that such a state of affairs in which the human rights of a certain human being are protected in a way that is adequate to certain cultural and civilizational circumstances in which he/she lives, is also due to him/her on the ontic basis. Therefore, we may observe that human beings have a right to legal protection of ontic human rights, protection adequate to certain civilizational conditions of existence. This right has certain obligational, normative consequences: people and their organisational forms (such as states) are obliged to strive to protect these rights, adequate to cultural and civilizational conditions. This leads to such a state in which norms protecting human rights would be at the same time in force because of the independently ontic and thetical justifications, so that the ontic and positive laws of human rights would be parallel.

The normative consequences of (ontic) human rights can be described by the use of an instrument we know well, that is, a system of norms. By norm we understood a prescriptive statement ordering certain subjects (addressees) in certain circumstances (a scope of application) to conduct themselves in a certain way (a scope of regulation). A norm binds its addressees because of certain facts justifying the fact that it is in force. On the basis of the nature of these facts, we can distinguish four groups of justification. In this case, the examined norms of laws of human rights are justified ontologically.

Every norm of this kind derives from a particular relationship between a human being and a certain state of affairs due to him/her, because they protect this relationship. These norms are in force because of this relationship.

While reconstructing these norms-consequences of a certain human right (norms that guarantee this right, actually, a certain state of affairs) we should bear in mind that 
they are in force because of ontic facts, they are justified ontologically and every attempt to reconstruct them will always be an attempt - accurate or inaccurate. Inaccuracy in this field may lead to disastrous effects, because it may result in non-recognition of the ontic rights that are due to a certain human being, especially rights to life. We have clearly seen where this can lead many times in history, e.g. in the totalitarian systems of communism and Nazism.

When analysing the current paradigm of human rights, we may reconstruct norms which the system of international protection of human rights consists of. Such a reconstruction will be based on an interpretation of acts of positive law. Having recognized these norms, we will be able to analyse them by the use of instruments of legal theory, such as concepts of legal situations and legal relationships.

\section{Human rights and positive law}

The relationships between human beings and states of affairs that were described above, when they become properly and accurately deciphered, may be treated as an objective basis for formulating standards for the protection of human rights. These "standards" are now expressed in many acts of positive law, in particular international and constitutional law. As M. Piechowiak observed, the provisions of acts of international protection of human rights indicate specified states of affairs that are protected. This indication has two function $\mathrm{s}^{35}$ : proclamative, that is it refers to an element of objectively existing reality, and legalising (or maybe: normative), that is it expresses a specific norm of positive law.

\section{Conclusion}

Specific rights due to human beings, called human rights, must be examined in detail. The previously raised concept of human rights as relationships between a human being (a subject) and a state of affairs that is due to him (an object) because of his/her dignity seems to accurately describe reality. These objectively existing relationships have their normative consequences which may be described by the use of norms (understood in the way that has been worked out within the so called Poznan school of legal theory). These norms are ontologically binding, the fact that they stay in force is justified ontologically. A lawgiver who declares the inherency and, at the same time, the objectivity of human rights and human dignity must accurately decipher these rights and their consequences and, subsequently, provide adequate positive legal means of protecting and guaranteeing them. Thus, adequate norms (binding because of thetic justification) must be enacted, consistent as to the content of the norms of the ontic law of human rights. In conse-

35 M. Piechowiak, Filozofia prawa..., p. 142-143. 
quence, what must be strictly differentiated is the concept of human rights and the concept of the law of human rights. The first must be understood as a set or system of ontic relationships between a certain human being and a state of affairs that is due to him $/$ her because of his/her dignity. The second is a system of norms that protects and guarantees these relationships; they are always ontologically binding, but they should also be thetically binding because of the fact that they have been enacted in a proper form by a competent authority. What must also be observed is the fact that enacting norms of positive law does not (and cannot) violate human rights (because of the very ontology of these rights), but it must be clearly seen that the purpose of positive law of human rights, as a substantive law, is to guarantee values, in all three possible meanings of the phrase "law guarantees" ${ }^{\prime 36}$. This attribute of positive law possibly justifies the pseudo-positivisation or even pseudo-constitutionalisation of human rights.

\section{SUMMARY \\ Human rights and the law of human rights: a positive legal regulation of an ontic reality}

The author introduces a fundamental distinction between human rights and the law of human rights which is subsequent to these rights. While examining these issues, the author follows M. Piechowiak and his way of understanding human rights. According to Piechowiak, human rights are objectively existing relationships between a human being and a global good, welfare that is due to him/her. Particular aspects of this global good are what we used to call an object of a particular human right. Therefore, human rights have an ontic nature. These relationships have their normative consequences. It may be stated that these relationships ontologically justify that the norms protecting these rights (actually these relationships) stay in force. These relationships and the norms protecting them can be recognized. Notwithstanding what was stated above, human rights shall be proclaimed and the ontic norms protecting them, adequately recognized, shall be positivised, that is, acts of positive law shall introduce these norms into legal systems.

Keywords: Human rights, theory and philosophy of law, ontic perspective

36 J. Mikołajewicz, Zasady orzecznicze Trybunatu Konstytucyjnego. Zagadnienia teoretyczno-prawne, Poznań 2008, pp. 98 - 100. 
228 | Adam Mickiewicz University Law Review 